<原 著 $>$

肝細胞癌に対する肝動脈塞栓療法後の肝障害対策

一高圧酸素療法の有用性に関する研究一

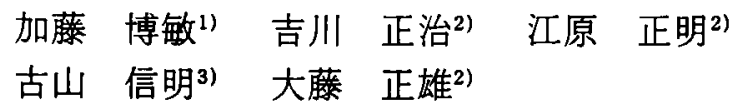

要 旨：肝動脈塞栓療法 (TAE) 後の虚血性肝障害に対する高圧酸素療法 (HBO) の有用性に ついて検討した。基礎実験で, HBOは門脈阻血により低下したラット部分阻血肝モデルの動脈 血中ヶトン体比（AKBR）を有意に改善した。肝硬変合併肝細胞癌症例44例を対象とした randomised study において, TAE 直後に低下した AKBR が, TAE 直後より HBO を施行した群 (TAE-HBO 群)で 3 時間後より有意に改善した。プロトロンビン時間は TAE-HBO 群で有意 に短縮した．血清フルブミン値，血清総ビリルビン值，治療後 1 年以内の主腫場の最大腫瘍縮 小率において，TAE-HBO 群と TAE 単独治療群の間に有意差は認められなかった。以上のご とく, HBOはTAEの抗腫場効果に悪影響を与えず, TAE 後の肝障害に対して, 肝内エネル ギー状態を反映する AKBR およびPTを早期より有意に改善する治療法であることが明らか となった。

卖引用語： 肝動脈塞栓療法（TAE）高圧酸素療法（HBO）肝細胞癌肝障害 動脈血中ヶトン体比 (AKBR)

緒 言

手術不能な肝細胞癌症例に対して肝動脈塞栓療法 (transcatheter arterial embolization: TAE) が広く 行われ良好な成績をおさめている。しかし, 肝細胞癌 の多くは進行した肝硬变症を合併しているため, TAE 後に重篤な肝障害が生じ予後を左右寸ることがあ る"．肝動脈阻血後の肝障害の主な原因は低酸素だ之 する報告"があることから，各種低酸素症，虚血性疾患 の治療法として既に確立している高王酸素療法 (hyperbaric oxygen therapy: HBO) ${ }^{3)}$ TAE 後に応 用し，有用性について険討した。 また，高濃度酸素の 投与と被塞栓動脈の再蹯通”济関連した虚血再灌流障 害(')可能性について，血清過酸化脂質を測定し検討 した. 尚, HBOの臨床応用に際して，予めラット部分 阻血肝モデルを作成して基礎的検討を行った。

\footnotetext{
1）放射線医学給合研究所重粒子治療センター治療・診 断部

2) 千葉大学医学部第 1 内科

3）千葉大学医学部附属病院手術部
}

<受付日1993年 6 月21日 >

\section{I. 基砧研究}

対象と方法

$250 \mathrm{~g}$ から $300 \mathrm{~g}$ （7 週齢～9 週龄）のWistar 系雄性 ラットを用い，4\%抱水クロラール溶液 $(1 \mathrm{~m} l / 100 \mathrm{~g}$, i.p.)にて麻酔後開腹し，肝中間葉拉よび左葉に流入す る門脈を結禁して68\%領域の門脈部分阻血肝モデルを 作成した. Fig. 1 に示した実験方法に従い, 次の 4 群 について検討した。Ｉ群：麻醉後, 開腹および閉腹手 術（シャム手術）のみを行った群（n=10）．II群：麻 醉後シャム手術のみを行い, 直後より HBO を行った 群 $(n=6)$. III群：麻醉後, 門脈部分肝阻血術を施行し た群 $(n=18)$. IV群：麻酔後, 門脈部分肝阻血術を施 行し，直後より HBO を行った群 $(n=10)$.

HBO は，動物実験用高仕タンク P-5100(福生会製) を用いて，純酸素により 3 絶対気圧 (atmosphere absolute：ATA）まで加圧し60分間施行した，加圧㧍よび 减王は各々15分間かけて行い, 全行程を90分間とした。 各群とも, 閉腹直後より90分後に再開腹し, 大動脈 よりへパリン採血したのち直ちに試験管ごと氷冷し, 血墏を遠心分離した。 $-80^{\circ} \mathrm{C}$ で涷結保存し， 1 週間以内 に肝内エネルギー状態を反映する動脈血中ケトン体比 


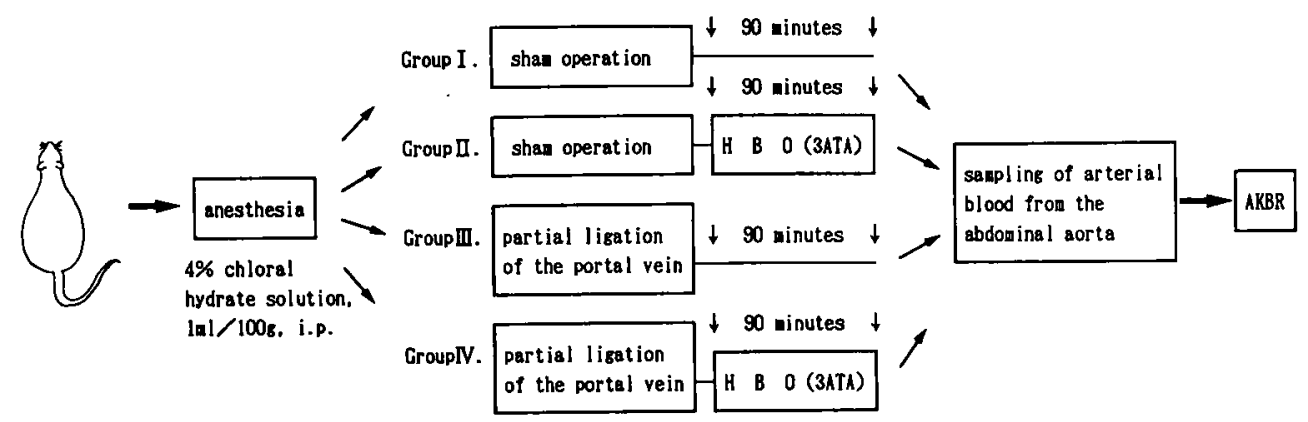

Fig. 1 Schema of the experiment on rats. ATA : atmosphere absolute

(arterial ketone body ratio: AKBR $)^{6)}$ を測定し, 4 群の平均値を比較した。

\section{II. 酶床研究}

1988年 8 月から1990年10月の間に，千葉大学第 1 内 科㧍よび関連施設にて肝細胞癌と診断されTAEの対 象とされた肝硬变合併肝細胞癌症例を, TAE 直後よ り HBO を施行する群 (TAE-HBO 群) と, TAE 単独 治療群 (TAE 群) とに分けて randomised studyを 行った。各群22例，計44例であった。両群の TAE 施行 前の臨床所見と検查所見を Table に示した. 肝細胞癌 および肝硬変の診断は全例, US, CT, 腹部血管造影等 の画像診断と，針生模による組織診断により行った。

TAE は大郍動脈より Seldinger 法によって行い, マ イトマイシンC $20 \mathrm{mg}$ とアトリフマイシン $30 \mathrm{mg}$ の動 注後，1２mm 角のゼラチンスポンシ（スポンゼル） を用いて塞栓を行った。塞栓部位は，TAE-HBO 群が 固有肝動脈18例, 右肝動脈 3 例, 左肝動脈 1 例で, TAE 群が固有肝動脈14例, 右肝動脈 7 例, 左肝動脈 1 例で あった。

HBO は，第 2 種の大型高気压酸素治療装置, KHO302型（川崎エンジニアリング社製）を用いて行った。 15分間の空気加压による2ATA 環境下で, 吸入マスク から100\%酸素を45分間吸入した後，减圧に15分間かけ た. TAE 施行後 3 時間以内に第 1 回目の HBOを行 い, 翌日より週 5 回連日施行し， 2 週間で計 10 回施行 した.

TAE-HBO 群とTAE 群において，以下の項目につ いて検討を行った。

\section{1. 肝機能検查}

TAE 後の肝障害に関して, AKBR, プロトロンビン 時間（PT)，血清アルブミン値 (Alb)，血清総ビリル
Table Characteristics of the patients.

\begin{tabular}{|c|c|c|c|}
\hline Clinical factor & TAE-HBO group & TAE group & Significance \\
\hline No. of patients & $22(11)$ & $22(11)$ & N.S.(N.S.) \\
\hline Age (yrs) & $\begin{array}{c}60.8 \pm 6.2 \\
(59.6 \pm 7.7)\end{array}$ & $\begin{array}{c}60.1 \pm 7.0 \\
(58.9 \pm 6.6)\end{array}$ & $\begin{array}{l}\text { N.S. } \\
(\mathbf{N} . \mathbf{S} .)\end{array}$ \\
\hline \multirow[t]{2}{*}{ Sex } & $18(11)$ & $19(9)$ & N.S.(N.S.) \\
\hline & $4(0)$ & $3(2)$ & N.S.(N.S.) \\
\hline Child's $\quad$ A & $15(8)$ & $17(8)$ & N.S.(N.S.) \\
\hline classification & $6(2)$ & $5(2)$ & N.S.(N.S.) \\
\hline $\mathrm{C}$ & $1(1)$ & $0(1)$ & N.S.(N.S.) \\
\hline ICG.R15 & $\begin{array}{c}26.6 \pm 13.3 \\
(28.5 \pm 13.2)\end{array}$ & $\begin{array}{c}22.8 \pm 11.0 \\
(28.6 \pm 11.7)\end{array}$ & $\begin{array}{l}\text { N.S. } \\
(\mathbf{N} . S .)\end{array}$ \\
\hline $\begin{array}{r}\text { Prothrombin time } \\
\text { (sec) }\end{array}$ & $\begin{array}{l}12.0 \pm 0.6 \\
(12.2 \pm 0.5)\end{array}$ & $\begin{array}{c}12.1 \pm 0.5 \\
(12.3 \pm 0.6)\end{array}$ & $\begin{array}{l}\text { N.S. } \\
(\mathbf{N} . \dot{S} .)\end{array}$ \\
\hline $\begin{array}{l}\text { Maximal diame- } \\
\text { ter } \\
\text { of a main tumor } \\
(\mathrm{mm})\end{array}$ & $\begin{array}{c}36.6 \pm 13.2 \\
(38.1 \pm 16.7)\end{array}$ & $\begin{array}{c}39.2 \pm 19.7 \\
(43.0 \pm 17.1)\end{array}$ & $\begin{array}{l}\text { N.S. } \\
\left(\mathbf{N} . \dot{S}_{\text {. }}\right)\end{array}$ \\
\hline \multicolumn{4}{|l|}{ embolized artery } \\
\hline PHA & $18(11)$ & $17(9)$ & N.S.(N.S.) \\
\hline RHA & $3(0)$ & $4(2)$ & N.S.(N.S.) \\
\hline LHA & $1(0)$ & $1(0)$ & N.S.(N.S.) \\
\hline
\end{tabular}

mean \pm S.D.

( ): data of the patients for measurement of serum lipid peroxide (LPO) and their statistical significance

N.S. : not statistically significant (t test or $x^{2}$ test), TAE : Transcatheter Arterial Embolization, HBO : Hyperbaric Oxygen Therapy, PHA: Proper Hepatic Artery, RHA : Right Hepatic Artery, LHA: Left Hepatic Artery

ビン值 (T. Bil) の経時的な変化について検討した。 た，肝阻血と高濃度酸素の投与による脂質過酸化の影 響を検討するために，第1例から第22例むで（TAEHBO 群11例，TAE 群11例) は, 静脈血清中の過酸化 脂質 (lipid peroxide : LPO)の経時的変化を測定した。

$\mathrm{AKBR}$ は TAE 直前, TAE 直後，3時間後，18時間 後, 3 日後, 1 週間後, 2 週間後に測定し, PT, Alb, 
T. Bil は, TAE 直前, TAE18時間後, 3 日後, 1 週 間後， 2 週間後に測定した. LPOは TAE 直前, TAE 直後， 8 時間後，18時間後， 3 日後，1週間後， 2 週 間後， 3 週間後に測定した. 動脈血中ヶトン体比(arterial ketone body ratio: AKBR) 測定のための動脈血 採血に際して血糖維持 $(120 \mathrm{mg} / \mathrm{d} l$ 以上)が望ましいと

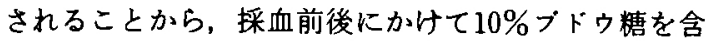
んた維持液 $500 \mathrm{~m} l$ の点滴を行った. $\mathrm{AKBR}$ は, 測定用 試薬ケトレックス「三和」および湘定機器 KETO. 340 (三和化学研究所) を用いて Williamson 法7”基つ いて動脈血中のアセト酢酸および3ーヒドロキシ酪酸を 測定し，その比（アセト酢酸/3ーヒドロキシ酪酸）とし て求めた。

LPO の測定は過酸化脂質定量試薬デタミナーLPO （協和メデックス）を用いて，八木別法㫙に基ついて 行った。

\section{TAEの抗腫場効果}

TAE 後の主腫汮の畽瘍樎小率を算出し，治療後 1 年以内に拁ける最大腫場縮小率（観察し得九畽瘍縮小 率の最大値)について検討した。瘇煌縮小率は，CT たは超音波検査にて求めた同一平面上でそれぞれに直 角に交わる腫場の最大径の積を用いて，〔(治療前の 積一治療後の積 $) /$ 治療前の積 $] \times 100(\%)$ に上り算出し た。

群間の有意差挨定は， $x^{2}$ 娭定， $\mathrm{t}$ 検定もしくは Mann-Whitney 模定を用いて行った。測定値の経時的 变化の有意差検定は， $\mathrm{t}$ 検定もしくはWilcoxon 検定 を用いて行った，有意水準は $5 \%$ \%下とした。

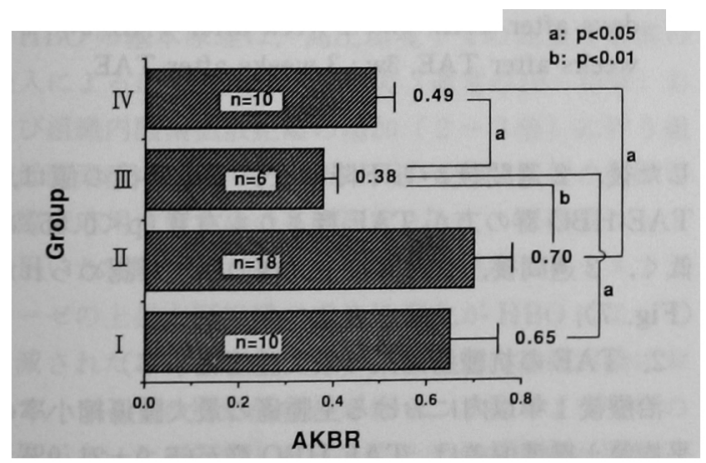

Fig. 2 The values of AKBR of rats. Vertical bars represent $\mathrm{SE}$.

Group I $(n=10)$ : sham operation. Group II $(n=$ 6) : sham operation and HBO. Group III $(n=18)$ partial ligation of the portal vein, Group IV $(n=$ $10)$ : partial ligation of the portal vein and $\mathrm{HBO}$
尚，本研究における娭査および治療は，十分な趣旨 説明の後，患者の承諾を得てから行った。

\section{成 績}

\section{I. 基礎研究}

各群の AKBR の平均值土標準誤差は，麻酔後シャ ム手術のみを行った I 群が0.65 $00.10(n=10)$, 麻酔 後シャム手術を行い，直後より HBOを行ったI群が $0.70 \pm 0.08(n=6)$ ，麻酔後門脈部分肝阻血術を施行し たIII群が0.38 00.03（n=18），麻酔後門脈部分肝阻血 術を施行し，直後より HBOを行ったIV群が $0.49 \pm$ $0.04(\mathrm{n}=10)$ であった（Fig. 2).AKBR の平均值に おいて，III群はI群に比べて有意 $(\mathrm{p}<0.05)$ に低く， また, IV群はIII群よりも有意 $(\mathrm{p}<0.05)$ に高い値を示 した.I群とII群の間には有意差は認められなかった。

\section{II. 臨床研究}

1. 肝機能検查所見

AKBR に関しては, TAE-HBO 群では TAE 直後に 前値に対して有意 $(p<0.05)$ に低下した值が， 3 時間 後には前値まで回復し，18時間後（翌日）（p<0.01） および 3 日後 $(p<0.01)$ に有意の高值を示した。一方， TAE 群では，直後（p<0.01）および 3 時間後 $(\mathrm{p}<$ 0.05）にも有意の低下を示したが，18時間後に前値ま で回復した後は有意の変化は見られなかった，2群間 の差の恰定では， 3 日後および 1 週間後に TAE-HBO 群が TAE 群よりも有意 $(\mathrm{p}<0.05)$ に高い値を示した (Fig. 3)，一般生化学検査では，PTにおいて，TAE$\mathrm{HBO}$ 群で 3 日後 $(\mathrm{p}<0.01)$ と 1 週間後 $(\mathrm{p}<0.05)$ に 有意の短縮を示し， 3 日後の值は TAE 群よりも有意

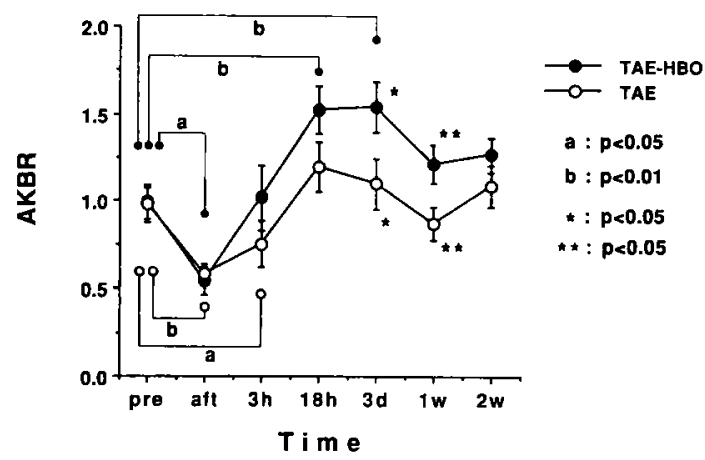

Fig. 3 Serial changes of AKBR after TAE. The values are expressed as mean $\pm \mathrm{SE}$. pre: just before TAE, aft : just after TAE, $3 \mathrm{~h}: 3$ hours after TAE, 18h: 18 hours after TAE, $3 \mathrm{~d}: 3$ days after TAE, $2 w: 2$ weeks after TAE 


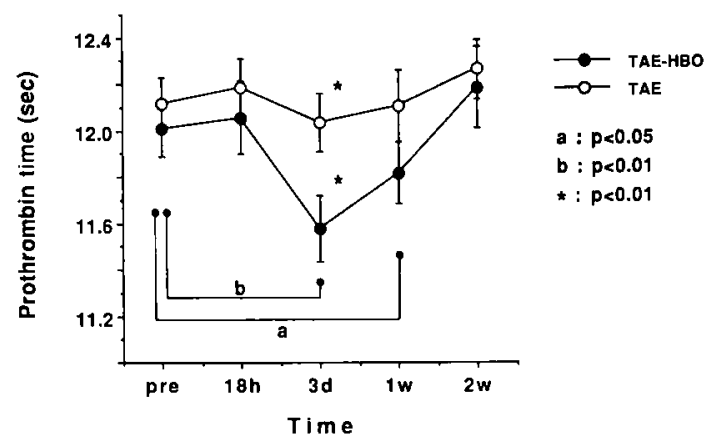

Fig. 4 Serial changes of PT after TAE. The values are expressed as mean $\pm \mathrm{SE}$.

pre : just before TAE, 18h: 18 hours after TAE, 3 $\mathrm{d}: 3$ days after TAE, $1 \mathrm{w}: 1$ week after TAE, $2 \mathrm{w}$ : 2 weeks after TAE

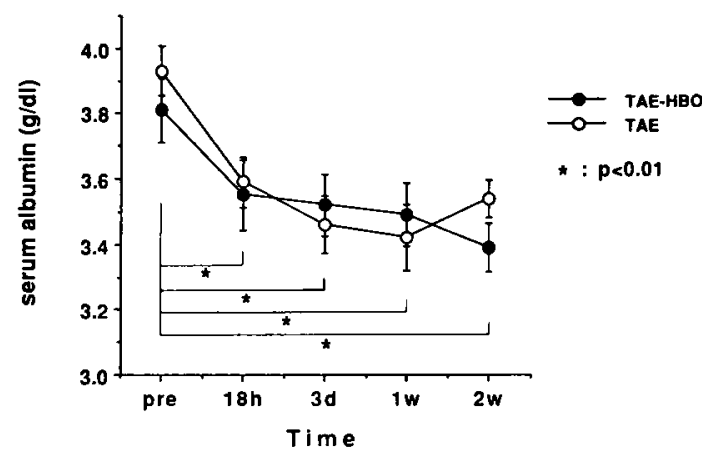

Fig. 5 Serial changes of Alb after TAE. The values are expressed as mean $\pm \mathrm{SE}$.

pre : just before TAE, 18h: 18 hours after TAE, 3 $\mathrm{d}: 3$ days after TAE, $1 \mathrm{w}: 1$ week after TAE, $2 \mathrm{w}$ : 2 weeks after $\mathrm{TAE}$

（p<0.01）に短かった，TAE 群では有意の変化が認め られなかった（Fig．4）。Albは両群ともTAE 18時間 後から 2 週間後をで有意 $(\mathrm{p}<0.01)$ の低下が持続した か， 2 群間で有意の差は認められなかった (Fig. 5)。 T. Bil は，両群とも TAE 18時間後から有意に上昇し (18時間後， 3 日後， 1 週間後: $p<0.01) ， 3$ 日後に最 大に達した後下降し， 2 週間後に前値に戻った。 2 群 間に有意差は認められなかった(Fig. 6)。LPOに関し ては, TAE-HBO 群ではTAE 8 時間後から前值に対 乙て有意 ( 8 時間後，18時間後， 1 週間後， 2 週間後, 3 週間後: $p<0.05)$ の高值を示し， 3 日後に最大と なった後下降した，TAE 群では，TAE 後徐々に上昇 し 1 週間後に前值に対して有意 $(p<0.05)$ の高値を示

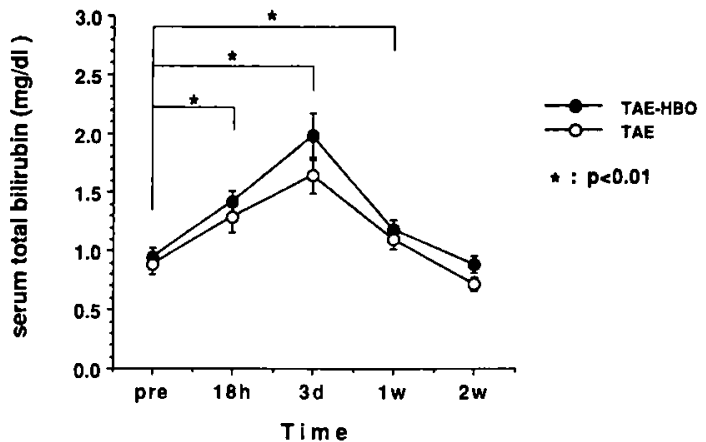

Fig. 6 Serial changes of T. Bil aftor TAE. The values are expressed as mean $\pm \mathrm{SE}$. pre : just before TAE, $18 \mathrm{~h}: 18$ hours after TAE, 3 d : 3 days after TAE, $1 w: 1$ week after TAE, $2 w$ : 2 weeks after TAE

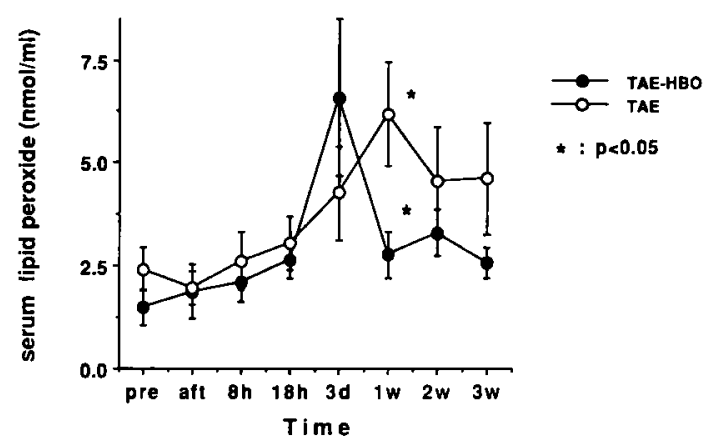

Fig. 7 Serial changes of LPO after TAE. The values are expressed as mean $\pm \mathrm{SE}$.

pre : just before TAE, aft : just after TAE, $8 \mathrm{~h}: 8$ hours after TAE, 18h: 18 hours after TAE, $3 \mathrm{~d}: 3$ days after TAE, $1 w: 1$ week after TAE, $2 w: 2$ weeks after TAE, $3 w: 3$ weeks after TAE

した後， 2 週間後から下降した。 1 週間後の值は, TAE-HBO 群の方が TAE 群よりも有意 $(\mathrm{p}<0.05)$ に 低く，2 週間後， 3 週間後も同様の傾向が認められた (Fig. 7).

2. TAEの抗腫瘍奻果（最大腫煌樎小率） 治療後 1 年以内における主腫瘍の最大腫瘍縮小率の 平均値士標隻偏差は, TAE-HBO 群か $66.9 \pm 21.9 \%$, TAE 群が69.5 23.0\%であり，両群間に有意差は認 められなかった。

尚，Tableに示したと括り，2 群の背景因子（症例 数，平均年齢，性別，Child 分類，ICG- $\mathrm{R}_{15}, \mathrm{PT}$, 主喱 場の最大長径, 肝動脈塞栓部位）に有意美は認められ 
なかった。

\section{考 察}

肝細胞は門脈および肝動脈による 2 重支配を受けて いるが, 進行した硬変肝では門脈圧六進により動脈支 配の比率が正常肝よりも高〈き，また，大部分の肝細胞 癌症例は進行した肝硬変症を伴らので，肝動脈を塞栓 する治療法である TAEでは術後に虚血性の肝障害を 生じることが少なくないい，肝動脈の阻血により肝酸 素供給量, 肝酸素消費量とも著明に低下し ${ }^{10)}$, 肝のタン パク合成能および ATP 量が有意に低下する2)ことが 報告されており，さらに，急速な肝障害の増悪により， $\mathrm{TAE}$ 後 6 力月末満の早期に肝不全死する症例がみら れるとの報告むある11. 本研究では, HBOが肝内低酸 素状態を改善し, 肝細胞内エネルギー産生能をえ進さ せることによって TAE 後の肝障害を軽減するかどう かについて検討を行った。ささらに，肝動脈塞栓後に高 濃度酸素を投与することに関して，活性酸素発生の問 題と TAEの抗腫場效果に与える影響についても検討 を行った。

$\mathrm{TAE}$ 後の各種血清酵素値の上昇は, 非癌部肝組織 の虚血性変化のみならず, TAEの抗腫瘍効果に起因 する癌組織の变性, 壊死にも由来すると考えられ, $\mathrm{TAE}$ 後の肝障害とその治療といら観点からみた場 合，適当な指標にはなりにくいと思われた。一方, AKBRは肝ミトコンドリフのエネルギー産生能を反 映し, 代謝面からみた即時的な肝予備能の指標として, 術後肝不全や肝移植の際などに用いられている ${ }^{12)} と$ から，本研究においてもAKBRを肝予備能の指標の 一つとして用いた。

$\mathrm{HBO}$ の基本原理は，高王環境下での高濃度酸素の 吸入による血漿酸素分圧の増大（通常の10～15倍）お よび組織内酸素扗散距離の増加（2－3倍）に伴う組 織低酸素症の改善である ${ }^{13)}$. HBOを TAE 後の肝障害 に臨床応用するための基礎研究として, 肝硬変ラット を用いた実験(4)があり，肝動脈結禁後のトランスフミ ナーゼの上昇と肝組織の虚血性変化が HBOによって 軽减されたと報告されている。本研究の基礎実験にお いて,ラットの肝動脈は径が細く, 本数打よび走行の 変異が多いため安定したTAEモデルの作成が困難と 考えられたので，部分肝阻血の方法として，門脈血と 大循環系の交通が維持でき, 循環動態の变動が少ない と考えられる肝 $68 \%$ 領域の門脈のみの結禁を行った。 我々が作成したこのモデルでは，部分肝阻血直後より 施行した HBOによって AKBRが有意に改善され,
HBO が，阻血部分肝において阻血を免れた血管系す なわち肝動脈を介して肝細胞内の低酸素状態を改善し た可能性が示された。しかしながら，ウサギ部分肝切 除モデルを用いた実験6)で，非切除肝の代償性機能元 進による肝エネルギー状態およびAKBRの上昇が報 告されており，HBO が非阻血部分肝における代償性 機能元進を促進し, 肝全体として低下したエネルギー 産生能を見かけ上六進させた可能性も考えられた。 た，部分肝切除モデルでは，肝切除後ごく早期（12時 間以内）にAKBRが急激に低下し，AKBR および肝 エネルギー状態が最も低下する12時間から24時間以内 の時期に死亡率が高いと報告されている的。我々の部 分阻血肝モデルにおいても阻血後直ちに AKBRの著 明な低下が見られ，障害発生後ごく早期に，肝エネル ギー状態すなわちその指標としてのAKBRを上昇さ せるよ5な观置をとることが, 生命予後を改善する上 で大きな意味を持つものと考えられた。臨床研究にお いて, TAE 直後の AKBR は両群とも, 予後危険 ${ }^{12}$ 之 されている0.7を下回る0.6以下に低下したが, TAE 3 時間後の值は, TAE 群が0.7程度に留まったのに対 して, TAE-HBO 群では1.0以上に回復し, その後も 3 日目まで有意の高値を保った。このことは，HBOが， $\mathrm{TAE}$ 直啳に生した肝ェネルギー産生能の低下を速や かに改善し，肝のエネルギー状態を元進させたことを 意味すると考えられた。をた，HBOが PT の延長を有 意に改善したことから，HBOが肝機能の变化を短時 間で反映する血液凝固系タンパクの合成能を促進した 可能性が示唆された。しかしながら, HBO 施行例にお いても非施行例と比べて Alb，T. Bil の改善が見られ なかったことから，HBOは急性の肝障害を改善し、そ れによる死亡例を救命できる可能性を有するるのの, TAEに伴 5急性期以降の肝予備力の低下を改善する ことは困難であると思われた。

一方, 高濃度酸素の組織障害性に関する報告がみら れ，活性酸素の関与が論じられているが，2ATA，2 時 間以内の通常の HBOにおいては, 組織障害をむたら すことはないとされている15).HBO と活性酸素の関 係については, HBOにより確かに活性酸素は増加す るが，酸素自体が活性酸素除去物質の生体内合成を誘 導するとする報告(6)や，HBOによってスーパーオキ シド $\left(\mathrm{O}_{2}{ }^{-}\right)$の消去醥であるスーパーオキシドジスム ターゼ（SOD）が誘導されるとする報告 ${ }^{17}$ がある.

高濃度酸素投与に伴ら活性酸素生成とその影響を検 討するために，本研究では脂質過酸化の指標として血 
清過酸化脂質（LPO）の測定を行った，血清過酸化脂 質は，肝組織中の過酸化脂質をそのまま反映するるの ではないものの, ある程度の肝細胞障害を反映してい、 る可能性がある18)との報告がある.

TAE 後の肝障害として, 虚血そのものに起因する 障害の他に, 被塞栓動脈の再疎通に伴 5虚血再灌流障 害5が重要と考えられる，虚血後の血流再開時に反応 性に富んだ活性酸素が大量に生成し，脂質の過酸化が 促進され, 細胞膜やミトコンドリフ膜の障害から臓器 全体の機能障害に至るとする実験報告らが多くみられ る. 被塞栓動脈の再蹯通に関する報告では, 早いもの でも TAE後 1 2 週とされており ${ }^{19)}$, 本研究におけ るLPO の増加パターンでの 3 日目 (TAE-HBO 群),

1 週間目 (TAE 群)のビークは, 被塞栓動脈の再柾通 に伴ら変化としては時期的に早過きると思われた。再 灌流過程にかかわらず，虚血のみによっても脂質の過 酸化, 活性酸素やフリーラシ்カルの除去機構の低下が

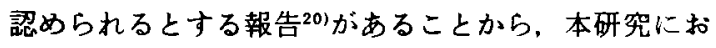
いて見られたLPOの潮増とピーク形成および急效な 下降は, TAEによる肝虚血により一時的に活性酸素 の生成が亢進し、その後、これを除去する機構が作動 したためと考えられた，TAE-HBO 群においてTAE 群よりもビークに達するまでの時間が短かったのは, 側副動脈むしくは門脈に上って肝虚血部分に高泹度酸 素が供給されたため, 活性酸素の生成が促進された可 能性が考えられる，最大に達した後の LPOの值は， TAE-HBO 群の方が TAE群よりる低い值を示した が、その意味として, 活性酸素除去機構が HBOにより 誘導, 賦活化された可能性 ${ }^{14-16)}$ と，虚血による活性酸 素除去物質の活性低下の程度か TAE-HBO 群におい てTAE 群よりも軽かった可能性，すなわち，HBOに より虚血自体による肝障害が軽減され, 活性酸素除去 物質の活性低下が軽减され, 結果としてLPOの生成 が抑制された可能性が考えられた. TAE-HBO 群にお いてみられた LPOの増加と急激な下降という時間的 変動は, 酸素耐性が獲得されたことを意味する可能性 があり，その本質はSOD，カタラーゼなどの活性酸素 除去物質の生体内での增加であると考えられてい $3^{14 \sim 16)}$.

TAEにより肝動脈を塞拴した後に高濃度酸素を投 与することの問題点は, 活性酸素の生成促進の可能性 と, TAEの抗腫瘍効果を弱める可能性である. 活性酸 素に関しては今まで述へててきたとおり，生体内除去機 構による無毒化が行われれば，酸素自体による虚血状
態の改善といら利益がもたらされ、 ミトコンドリアに おけるェネルギー産生能の保持から組織障害の回避へ とつながことになる. 今回の研究で, LPOが上昇し ているにもかかわらず, AKBRが TAE 3 時間後以降 正常值に保持されたのは，活性酸素の生成，脂質過酸 化に上る生体膜障害の程度が藏器全体としての機能低 下に結びっかない程度にとどまっていたことを意味す ると考えられた。 また，本研究の基礎実験において， HBO が正常ラットの AKBRを低下させなかったこ とは, HBO が単独で肝のエネルギー産生能に悪影響 を及ばさないことを示している.HBOがTAEの抗腫 瘍効果を弱める可能性に関しては, TAE 後の主畽漡 の最大腫殉縮小率において TAE-HBO 群と TAE 群 の間に有意差が見られなかったことから，HBOは TAEの抗腫痬効果に対しても悪影響を与えないと考 えられた。

\section{結語}

1. HBO は，正常ラットのAKBRに影每を与えず, 部分阻血肝モデルの AKBR を有意に改善した。

2. 臨床研究において, TAE 直後に低下した AKBR が, TAE-HBO 群でTAE 3 時間後から回復し、3 日 後および 1 週間後の值は TAE 群よりも有意に高かっ た.

3. PTは, TAE-HBO 群で TAE 3 日後と 1 週間後 に有意に短縮し， 3 日後の値は TAE 群よりも有意に 短かった。

4. Alb，T.Bilについて両群間に有意差は認められ なかった。

5. LPO は両群とも TAE 後上昇し，3日ないし1 週間後に最大に達した. 1 週間後以降は TAE-HBO 群 の方が TAE 群よりも低かった。

6. 治療後 1 年以内における主腫痬の最大腫瘍縮小 率は両群間に有意差が見られなかった。

以上より，HBOは，TAEの抗腫場効果に悪影晦を 与えず, TAE 直後の肝障害を軽減する有効な治療法 であることが明らかとなり，TAEの適応を厷げられ る可能性が示唆された。

謝辞：稿を終えるにあたり，高王酸素療法について御指 導いただいた千葉大学医学部附属病完手術部前部長, 豦口 道雄先生（現斉藤労災病院長）に深謝いたします。

本論文の要旨の一部は, 第31回日本消化器病学会大会に て発表した。 


\section{文 献}

1) 中尾宣夫, 三浦行矣, 高安幸生, 他：肝機能か、らみ た肝癌動脈塞栓術の適店の検討。日消誌 81 ： 1995-1999, 1984

2) Fornander J, Seeman T, Hasselgren $P O$, et al : Changes of protein synthesis in liver tissue following ligation of hepatic artery or portal vein in rats. Eur Surg Res 17:101-108, 1985

3）高橋英世，早瀬弘之，小林繁夫, 他：高気王酸素治 療の現況と問題点. 最新医学 $41: 216-224,1986$

4）平井賢治: Transcatheter arterial embolization 療法の基礎的検討一正常犬に拈ける塞栓後の肝動 脈，肝機能および肝組織の変化について一，肝缄 $24: 1012-1020,1983$

5）吉川敏一，小山田裕一，市川 寞, 他：肝の虚血再 灌流障害に対する活性酸素および脂質過酸化の成 与. 日消誌 $87: 199-205,1990$

6) Ukikusa M, Ozawa K, Shimahara $Y$, et al : Changes in Blood Ketone Body Ratio. Their significance after major hepatic resection. Arch Surg $116: 781-785,1981$

7) Williamson DH, Mellanby J, Krebs HA: Enzymatic determination of $\mathrm{D}(-) \cdot \beta$ Hydroxybutyric acid and acetoacetic acid in blood. Biochem J 82 : 90-96, 1962

8) Ohishi N, Ohkawa H, Miike A, et al: A new assay method for lipid peroxides using a methy. lene blue derivative. Biochemistry International $10: 205-211,1985$

9) 長与又郎：宿題肝硬变, 病理解剖学的方面. 日病会 誌 $4: 31-72,1964$

10）富山光広，伊藤清高，加藤紘之，他：肝動脈遮断後 の肝酸素需給動態と肝静脈酸素飽和度との関係に 威する実倹的検討. 䀒茂 $34: 18-22,1993$
11）磯村伸治, 江原正明, 大藤正雄, 他：肝細胞癌に対 する肝動脈塞栓療法の有用性一背景因子別にみた 長期予後の検討一. 肝喴 $32: 604-612,1991$

12）小澤和恵：肝歲外科における Redox 理論の提唱 とそれに準じた治㞠対策の確立。日外会誌 84 ： 753-757, 1983

13) Boerema I, Meyne NG, Brummelkamp WK, et al: Life without blood. A study of the influence of high atmospheric pressure and hyperthermia on dilution of the blood. J Cardiovasc Surg $1: 133-146,1960$

14) Mito $M, W u T$, Nakanishi $Y$, etal : Hyperbaric oxygen treatment after ligation of the hepatic artery in cirrhotic rat. 5th Int Hyperbaric Congress Proceedings $1: 317-324,1973$

15）太田保世：酸素の毒性々酸素中毒および高気圧酸 素治㞠. 最新医学 $41: 230-236,1986$

16) Kimball RE, Reddy $K$, Peirce $T H$, et al: Oxygen toxicity : Augmentation of antioxidant defence mechanisms in rat lung. Am J Physiol $230: 1425-1431,1976$

17) Gregory EM, Fridovich I: Induction of superoxide dismutase by molecular oxygen. J Bacter. iol $114: 543-548,1973$

18）小畑 満：ラット再生肝における過酸化脂質の検 討。 日外会誌 $93: 833-840,1992$

19）市田隆文，小島 隆，中野護，他：肝細胞癌に対 するTranscatheter arterial embolization 療法 の臨床病理学的検討. 第 1 報. 治療効果に関する研 究. 肝葴 $22: 1264-1275,1981$

20) Marubayashi S, Dohi K, Ochi K, et al : Role of free radicals in ischemic rat liver cell injury : Prevention of damage by $\alpha$-tocopherol administration. Surgery $99: 184-192,1986$ 


\title{
Hyperbaric oxygen therapy for hepatic dysfunction caused by transcatheter arterial embolization for hepatocellular carcinoma
}

\author{
Hirotoshi Kato*, Masaharu YoshIKaWA**, Masaaki EBaRA**, \\ Nobuaki FURUYAMA*** and Masao OHTO**
}

Forty-four patients with hepatocellular carcinoma $(\mathrm{HCC})$ and liver cirrhosis were randomized to be treated with Hyperbaric Oxygen Therapy (HBO) after transcatheter aterial embolization (TAE) for $\mathrm{HCC}$ or not to be treated with HBO. The HBO had been proved to have a good effect on the arterial blood ketone body ratio (AKBR) in the preliminary experiment conducted on rats with partial hepatic ischemia. The AKBR decreased immediately after TAE, but in the group treated with HBO (TAE-HBO group), this was followed by a rapid recovery above the control level. The AKBR in the TAE-HBO group was significantly higher than that in group untreated with HBO (TAE group) at three days and one week after TAE. The prothrombin time was shortened in the TAE-HBO group at three days and one week after TAE. There were no significant differences between the two groups in the maximal rate of decrease in tumor size evaluated within a year after TAE. These results demonstrate that HBO does not exert a bad influence on the anti-cancer effect of TAE and is a beneficial treatment for hepatic dysfunction arising just after TAE.

\footnotetext{
* Division of Radiation Medicine, Research Center of Charged Particle Therapy, National Institute of Radiological Sciences (Chiba)

** The First Department of Internal Medicine, Chiba University School of Medicine (Chiba)

*** Surgical Center, Chiba University Hospital (Chiba)
} 